\title{
Spor Müzelerinin Dijital Halkla İlişkiler Çalışmalarına Yönelik Bir İnceleme: Beşiktaş JK Müzesi Örneği
}

Esra ABRAK, Doktora Öğrencisi, Kocaeli Üniversitesi, Sosyal Bilimler Enstitüsü, Halkla iliş̧kiler ve Tanıtım Ana Bilim Dalı, 0000-0003-3495-4737 eabrak@gmail.com

ÖZ

\begin{abstract}
Spor kulüplerinin bünyesinde, spor tarihine dair tanıklkları nesilden nesile aktaran ve kulüp tarihine dair kişi, konu ve objeleri bir araya getiren spor müzeleri, günümüzde çağdaş müzecilik anlayışıyla birlikte yeni bir yapılanma içerisine girmiştir. Bu bağlamda, tasarımını ziyaretçi hedef kitlesini interaktif bir müze deneyimini yaşaması odaklı kurgulayan spor müzeleri; mevcut bilgilendirme misyonlarının yan sıra, ziyaretçi deneyimini esas alan dijital uygulamalar, etkinlikler ve sunduğu diğer seçeneklerle çă̆daş müzeciliğin spor odaklı alanında önemli bir görevi üstlenmektedir. Eş zamanl olarak hedef kitlesiyle güçlü bağlar kurmayl, yaptığı çalışmalarla ilgili bilgilendirmeyi amaçlayan spor müzeleri, koleksiyon ve mimarilerinde dijital odaklı bir yapıyı benimsemelerinin yanında, dijital halkla ilişkiler çalışmaları ile kendilerini tanıtmak, çalışmalarına yönelik bilgiler vermek ve müze ziyaretini destekleyici bir dizi stratejik iletişim faaliyetinde bulunmaktadır.

Bu çalışmada Türkiye'de T.C. Kültür ve Turizm Bakanlığı tarafindan tescilli ilk spor klübü müzesi olma özelliğine sahip Beşiktaş JK Müzesi'nin dijital halkla ilişkiler pratiklerinin belirlenmesi amaçlanmaktadır. Çalışma, ülkemizde önemli spor klüplerinden biri olan Beşiktaş JK bünyesinde yer alan, dijital halkla ilişkiler kullanım pratikleri anlamında da bir ilki temsil eden Beşiktaş JK Müzesi ile sınırlandırllmıştır. Gözlem ve örnek olay incelemesi yöntemlerinin kullanıldığı çalışmadan elde edilen veriler neticesinde dijital halkla ilişkileri pratiklerinin, yeni nesil spor müzeleri kavramı içerisinde yeri ve kullanım biçimleri ortaya konulmuştur.
\end{abstract}

Anahtar Kelimeler: Spor Müzesi, spor iletişimi, dijital halkla ilişkiler, Beşiktaş JK Müzesi

\section{Digital Public Relations Practices in Sports Museums: Beşiktaş JK Museum Case}

\footnotetext{
ABSTRACT Today sports museums which convey the testimonies of history of sports from generation to generation, bringing together the individuals, topics and objects related to the history of the sports clubs, are in a restructuring process with a contemporary museology approach. In this context; in addition to their existing mission of providing information, the sports museums, designed in order to create an interactive museum experience for their visitors, also play an important role in the sport-oriented field of contemporary museology with their digital applications, activities and other options that focus on the visitor experience. In addition to adopting a digitally oriented structure in their collections and architectures, sports museums aiming to establish strong ties with their target audience while providing information about their activities, carry out a series of strategic communication activities that support museum
} 
visits in order to make publicity through digital public relations, as they provide information about their activities.

In this study, Besiktas JK Museum, which is the first sports club museum registered by the T.C. Ministry of Culture and Tourism in Turkey, aims to determine the digital public relations practices. The study is limited to Beşiktaş JK Museum, which is using digital public relations practices. Data obtained from the study using observation and case study methods.

Keywords: Sports museum, sports communication, digital public relations, Beşiktaş JK Museum

\section{GíRIŞ}

Dünya spor tarihinde spor müzelerinin çeşitliliği ve kuruluş tarihleri oldukça oldukça erken dönemlerde başlamış olmasına rağmen, ülkemizde spor müzelerinin oluşumu çok daha yakın zamana dayanmaktadır.

20. yüzyılın peşi sıra getirdiği pek çok yenilik, bireyin hayatında pek çok değişikliğe yol açmıştır. Sanayileşme, işgücünün makinalarla uyarlanabilir iş modellerinin oluşması; beraberinde ekonomik ve sosyal değişimlerin yaşanması, serbest zaman kavramı ve faaliyetlerinin insan yaşantısına dahil olmasını sağlamıştır.

Pek çok serbest zaman uğraşısı gibi, spor da bireylerin ilgisini çeken, gerek bireysel deneyim olması, gerek oluşturulan takımların faaliyetlerini takip edip, taraftar olgusuna zemin hazırlaması ve bir endüstriye dönüşmesi açısından zaman içerisindeki devinimi itibarıyla dikkate değer bir inceleme alanı olmuştur.

Sporun temsil ettiği değerler bağlamında, sporun kapsadığı alan oldukça geniş ve etki gücü tartışılmazdır. Yıldız'a göre modern yaşamda spor her yerde bulunur veya bulunduğu kabul edilir. Öyle ki "Sporun, gençlerin yeğlediği eğlencelerden biri, aynı zamanda toplum bireylerinin çok beğendiği bir seyir haline gelmediği bir ülke kalmamıştır." (Yıldız, 1979: 16)

Spor kavramı, toplumların yapılanması, belli gereksinimlerini yerine getirmesi sonrasında, ihtiyaç duyulan, bireysel anlamda hayatın bir parçası haline dönüşmüş bir dizi faaliyetler dizgesine evrilmiştir. Serbest zaman faaliyetleri anlamında filizlenen spor, bugün gerek kulüp bazında, gerek peşi sıra geliştirdiği ürünlerle önemli bir ekonomik değerdir.

Erkal (1986:59) serbest zaman faaliyetlerinin yapılabilmesinin, bir ülkenin gelişmesi ile ilgili olduğuna değinir. Erkal, teknoloji üretebilen ve devamlı olarak yenileyebilen ülkelerin, serbest zaman faaliyetlerine imkan sağlayacak ortamı yaratarak, sporun gelişimine katkıda bulunmakta olduklarını belirtmektedir. Buradan da anlaşılacağı üzere, spor yaşayan bir değer ve nesilden nesile aktarılan bir kültürel birikimdir.

Sporun bireyin yaşamındaki yerine değinen Yıldız, (1979:16) sporun eğitimcilerinin bireyin kişilik oluşumunda ve kişilik niteliklerini geliştirmek amaçl önerilen bir disiplin olduğunu dile getirirken, buna ilave olarak yöneticilerin enerji şekillendirme ve mücadele anlayışı geliştirmek amaçlı kullandıkları bir metod olduğunu belirtmektedir. 
Sporun nitelikleri perspektifinden değerlendirildiğinde, sadece serbest zaman faaliyeti olmadığına değinen Erkal (1986:69) sporun eğitim, fizyoloji, psikoloji, sosyoloji, sağlık, gençlik, çalışma hayatı, sosyal güvenlik gibi alanlardan ve konulardan ayrı düşünmenin mümkün olmayacağına değinmektedir.

Sporun gerek birey bazında gerek toplum bazında ilgi görmesi, kitleleri peşinden koşturması, sporun zaman içerisinde bir endüstri haline gelmesine olanak yaratmıştır. Bir klüp markası içerisinde şekillenen spora yönelik ilgi, zamanla ciddi anlamda yönetilmesi gereken ve yüksek bütçelerin konuşulduğu, içerisinde, yönetim, sporcu, taraftar, marka yönetimi, spor iletişimi gibi çoklu değişkeni barındıran bir mecraya dönüşmüştür.

Spor endüstrisi yapısında hangi ölçekte olursa olsun, her spor kulübünün varlığının devamlılığı için, ilişki kurduğu tüm çevrelerle, çağdaş yönetim prensiplerini esas alan bir yönetim anlayışının gerekliliğinden bahseden Katırc1, (2009:66) endüstrileşen spor kulüplerinin sadece bilet, transfer ve medya gelirleri ile yaşamlarını uzun süre devam ettiremeyecekleri bir ortam oluşumundan bahsetmektedir. Günümüzde spor kulüpleri bir yandan gelir kalemlerini artırmayı hedeflerken, eş zamanlı olarak geniş kitlelere hitap etmek, marka değerini artırmak, toplum içerisinde popüler konumlarını korumak gibi hedefleri de benimsemektedir. Bu noktada da hedeflerine ulaşabilmek adına, yönetim stratejileri yanı sıra bir dizi düzenli iletişim faaliyetine başvurmaktadırlar.

Günümüz koşullarında spor kulüplerini pek çok farklı dinamik etkilemekte ve şekillendirmektedir. Spor kulüplerinin spor etkinlikleri kapsamındaki genel çalışmalarının yanı sıra (maçlar, müsabakalar vb. faaliyetler) zamanın dinamiklerinin getirdiği gereklilikler, sporun şirketleşmesi ve markalaşması yönünde adımlar atmasına sebep olmuştur. Farklı gelir kaynaklarına zemin oluşturan bu yapılanma içerisinde sürekli olarak hedef kitlenin algısını canlı tutmak özel bir çabayı gerektirmektedir. Örneğin “İngiltere'de Chelsea ve Manchaster United gibi ekonomik gücü elinde tutan ve spor pazarlamasında başarılı olan klüpler stadyumlarının yanında otel, restaurant, market ve hatta müze gibi hizmetleri yerleştirerek gelirlerini artırmak ve kitlelerin spor ürününü uzun sure tüketmelerini sağlamaktadırlar." (Velioğlu ve Çoknaz, 2007: 92-100) (Akt: Altunbaş, 2007:96)

Sporun zaman içerisinde bir tüketim nesnesine dönüşmesi, bu alanın bir dizi planlı tanıtım ve iletişim kuralları uygulama gerekliliğini ortaya çıkartmıştır. Bu bağlamda hedef kitlenin doğru analiz edilmesi ve bu noktada doğru iletişim stratejileri uygulamak gerekmektedir. Özellikle dijital unsurların ve sosyal medya kullanım alışkanlıklarının altın çağının yaşandığı, takipçi kültürünün kitlelere yayıldığ1 bir anlayış olduğu günümüzde, hedef kitleyi anlamak çok önemlidir. Zira spor kavramı, kitle kültürü oluşturması, tüketim değerine dönüşmesi ve ticarileşmesi anlamında çok büyük bir değişim değeri oluşturmaktadır. Dünyanın her köşesinden milyarlarca insan bu değerin bir parçası olmakta, maçlara gitmekte, markanın dükkanlarından alış veriş etmekte, müzesi, stadyum turu, restaurant, kafe gibi deneyim alanlarından faydalanmaktadır.

Ekonomik değer barındıran spor faaliyetlerinin daha geniş alanda etki yaratması amacıyla, planlı pazarlama çalışmalarının içerisine halkla ilişkiler faaliyetlerini de dahil etme durumuna zemin hazırlamış, tanıtım ve bağ kurma faaliyetlerinin gerekliliği, halkla ilişkiler 
pratiklerinin kullanılması ihtiyacını ortaya çıkartmıştır. Robinson (2007, Akt: Altunbaş, 2007:95) halkla ilişkilerin katma değeri anlaminda şu şekilde bahsetmektedir: "Spor pazarlaması için pazarlama bileşenlerini 5P ürün(product), yer (Place), fiyat( Price), promosyon (Promotion) ve halkla ilişkiler(Public Relations) olarak ön plana çıkarak sporun hem ürün hem de pazarlama iletişimi sürecini kolaylaştırmaktadır(Robinson 2007, Akt: Altunbaş, 2007:95).

\section{DEĞİŞEN MÜZECILIIK ANLAYIŞI VE SPOR MÜZELERI}

Müze kavramı çok temel olarak toplumların kültürel miraslarının muhafaza edildiği yerler olarak tanımlanabilir. Zaman içerisindeki üstlendiği roller, misyonundaki değişimler müzeciliğin devinimini temsil etmesi açısından dikkate değerdir.

Duruma spor müzeleri özelinde bakıldığında ise içerisinde çok farklı dinamikleri barındıran, canlı bir yapı ortaya çıktığı görülmektedir. Spor müzeleri ekosisteminde pek çok farklı unsuru barındırmaktadır. Bir yanda bahsi geçen spor klübünün kültürel birikimini ortaya koyması, diğer yanda bulunduğu alandaki şehrin kültürüne tanıklık etmesi ve katkıda bulunması, bütüne bakıldığında ise hem sporun hem de koleksiyonunu oluşturan unsurlar anlaminda ülke spor tarihine dair bilgileri sunması, spor endüstrisi ile birlikte düşünüldüğünde, ekonomik bir değer temsil etmesi adına önemli bir misyonu üstlenmektedir.

Günümüzde müzeciliğin izlediği "çağdaş müzecilik" anlayışının sonucu olarak, spor müzeleri de ziyaretçisi ile organik bir bağ oluşturmayı hedeflemekte, bu eksende deneyimi esas alan uygulamaları ve koleksiyonu ile çeşitli etkinlikler, atölyeler, sergiler düzenleyerek, hedef kitlesi ile bir iletişim bağı oluşturmayı esas almaktadır.

Spor faaliyetleri, serbest zaman faaliyetleri anlamında pek çok farklı alternatiften biri gibi görünse de, sporun temsil değeri anlamında çok daha geniş bir yelpazeyi oluşturmaktadır. Taraftar kültürü, klüp yönetimi, marka değeri, sporcular, maçlar, hikayeler, ritüeller gibi pek çok değeri barındırmaktadır. Kültürün önemli dayanak noktalarından birini oluşturan spor, nesilden nesile aktarılması ve birleştirici gücü anlamından çok daha özel bir yere sahiptir.

Spor müzelerinin bulundukları ülkenin spor gelişiminin ve spor kültürü birikiminin resmini sunmakta olduğunu belirten Korkmaz (2013: 66), müzelerin bunu yaparken pekçok farklı yöntemi kullanıp, çeşitli etkinlikler ve uygulamalar geliştirdiklerini söylemektedir. Bu bağlamda spor müzeleri spor tarihine yönelik koleksiyonları sergilemeyi ana amaç edinirken, eş zamanlı olarak koleksiyonu ekseninde çeşitli etkinlikler, promosyon faaliyetleri ve deneyim alanları sunmaktadır.

Müzeler ve kültür mecralarına yönelik genel düşünce kalıbı, erişilmez ve yüksek kültür kavramı ile ilişkilendirilmektedir. "Halen müze, tiyatro, konser ve resim sergilerine giderek elde edilen "yüksek kültür" karşısında, futbol ve genel olarak sporun hala "düşük kültür" seviyesinde olduğuna dair çarpık bir düşünce vardır. Bununla birlikte futbol, artık ilçe ve kent kültürünün bir parçası olarak kabul ediliyor. Bu durum, Liverpool ve Glasgow'daki 
müzelerde yer alan birkaç futbol sergisi (Moore 1997) ve tam olarak Preston'ın Ulusal Futbol Müzesi'nde kendisini gösterir." (Bridgewater, 2012: 129)

İçinde yaşadığımız yüzyılın getirdiği teknolojik gelişim ve uygulamalar, pek çok çalışma alanını etkilediği gibi, müzecilik sergileme ve ziyaretçiye yönelik hizmetlerin içeriklerinin şekillenmesi ve sunumuna da etki etmiştir. Teknoloji müze içi koleksiyon ve sunumlarda etkili olduğu kadar, sosyal medya pratiklerinin bir ifade biçimine dönüşümünü olanaklı kılmıştır.

Bu sayede ziyaretçi, müze içerisinde düzenlenen çalışmalar ve hizmetlerden haberdar olabilmekte, farklı bir coğrafyada yer alan müzeye web üzerinden anında erişebilmekte, mobil uygulamalar vasıtasıyla dijital içeriklerden istediği türde bilgiyi edinebilmektedir.

Bu araçlar aracığılıyla, müzeciliğin ana misyonlarından spor bilinci kazandırmak, ziyaretçiye spor tarihi konusunda sürekli bilgiye erişim imkanı yaratmanın yanı sıra bilgiye erişmek isteyenlere yönelik araştırma imkanı sunmak, serbest zaman faaliyeti anlamında çeşitli seçenekler sunmak mümkün olabilmektedir.

Korkmaz, (2013:106) müzelerin vizyonunu şu şekilde tanımlamaktadır:

“Toplumu sporla tanıştırmak, spordaki değişim ve gelişmelerin kavranmasını ve spor bilincinin gelişmesini sağlayıp yaşam kalitesini yükselterek toplumla bütünleşmek ve evrensel değerlere sahip olarak bilimsel ve teknolojik açıdan uluslararası standartlardaki çağdaş spor müzeleri arasında yer almak."

Spor müzelerinin, günümüz ve ilerleyen dönemlerdeki hedeflerine yönelik olarak iletişim yapılarında teknoloji ve dijital iletişim prensiplerini benimsemesi önemli bir gerekliliğe dönüşmektedir. İletişim faaliyetleri, müzenin ne yaptığını anlatması kadar, iletişimin hedef kitlesi ile sürekliliğini sağlamak açısından vazgeçilmez bir gerekliliğe dönüşmüştür.

“Günümüzde spor kulüpleri kurumsal yönetimin temel gereklerinden biri olarak iç ve diş çevrelerindeki tüm unsurları kapsayan bir ilişki ağ1 geliştirmekte ve bu ilişkiyi çağdaş yönetim anlayışları ile yönetmektedirler. Spor kulüplerinin iç ve diş çevreleri ile kurdukları ilişkilerin yönetiminde iletişim yönetimi ve/veya kurumsal iletişim olarak adlandırılan yapı ile karşılaşılmaktadır." (Katırcı ve Uztuğ, 2009: 150)

Sürekli ve planlı bir dizi stratejik adımı içeren iletişim faaliyetleri, müzenin ne yaptığını anlatmasının yanında, ne yapmak istedikleri ve ne tür deneyimleri de vaat ettiklerini anlatmaları açısından da önemlidir. Bugünün çağdaş müzecilik anlayışında, müzenin koleksiyonunu ve çalışmalarını ne kadar iyi anlattığı sorunsalının yanı sıra ne tür deneyimleri sunduğu noktası da üzerinde durulması gereken kısmını oluşturmaktadır.

Bridgewater (2012:162) futbol markaları için dört deneyim türünden bahsetmektedir. Bu deneyimler sırasıyla, eğitici (öğrenmek), eğlendirici (hissetmek), estetik (olmak) ve gerçeklerden kaçış (yapmak) şeklinde sınıflamaktadır. Müze deneyimini estetik (olmak) başlığında değerlendiren Bridgewater (2012:162) bu durumu şu şekilde tanımlamaktadır. “Bazı klüpler stadyumun içinde mükemmel barlar, üye barları veya müze alanları 
yaratmıştır. Bunlar taraftarlar için bir atmosfer oluşturmak adına hatıraları, maç yayınlarını ve önceki stadyumun mimari yapısını bile bir araya getirmektedir.

Bu noktadan hareketle, spor ve bileşenlerinin toplulukları etkilemesi, iyi zaman geçirme, heyecan ve coşku yaratma, aidiyet hissi oluşturmasının yanı sıra vadettiği önemli bir deneyim çeşitliliği de söz konusudur. Bugün spor kültürünü temsil eden ve günümüze uyarlanmış uygulamalarıyla tasarlanan spor müzeleri, ziyaretçiye kronolojik bir bilgi sağlamanın ötesinde, duyularını harekete geçiren çoklu deneyimler dizgesi olarak karşımıza çıkmaktadır.

Sosyal medya pratiklerinin müzeciliğe uyarlanması sonrasında oluşan karşılıklı etkileşim, müze ziyaretçilerini öncelikle kendilerine sunulan yepyeni bir dünyanın kapılarını aralar duruma dönüşmüştür. Ziyaretçi hem kendisine sunulan yeni bir tüketim alanından haberdar olmuş hem de tercihleri arasına yeni bir alternatif katmıştır. Bunun sonucunda müzeler de koleksiyonları ve sahip oldukları kültürel belleğe ilave olarak yeni bir rolü üstlenmiş, haber ve içerik üreten bir mecraya dönüşmüştür.

\section{SPOR MÜZECILIIĞí ANLAYIŞINDA DİJiTAL HALKLA İLIŞKKILERIN YERİ VE ÖNEMİ: BEŞIKTAŞ JK MÜZESI ÖRNEĞİ}

Günümüz koşullarında milyonlarca tüketici hedef kitlesine hitap eden, anlık iletişimi destekleyen iş modelleri, tüketici ile daha yakından ve hızlı iletişim seçeneklerini kaçınılmaz bir hale getirmiştir. Tüketici ve karşısında bağ kurduğu kurum, kuruluş ve organizasyon yapısı ile anında iletişimde olmayı talep etmekte ve bilgi ve geri bildirim almadığı takdirde ilgi odağını, tercihlerini hızlıca farklı bir kurum ya da hizmet sağlayıcıya yönlendirebilmektedir. Tüketim işleyiş sürecinde ürün ve hizmet sağlayan her kuruluş için hatırlanır olmanın en temel gereklilikleri aidiyet, bağ kurma, etkileşim kavramlarından geçmektedir. Bu noktada geniş kitlelere hitap etmesi ve çok yönlü olması dijital halkla ilişkileri ön sıralara taşıyan önemli etmenlerdir. Bunun yanı sıra diğer önemli bir bileşen ise, tüketicinin sürece dahil olma isteği ve birebir vaat edilen deneyimi yaşamaya yönelik olgudur. Serbest zaman aktivitelerinin çoğunda sunulan aktivitenin çeşitliliğinden çok, tüketiciyi sürecin içerisine ne kadar dahil ettiği konusu, durumun en önemli yönünü teşkil etmektedir.

Tüketim, serbest zaman olgusunun ana eksenini oluşturmaktadır. Bir dizi süreçleri takip eden bu oluşumda, pek çok bileşen bu duruma dahil olmaktadır. "Tüketim süreci tüketim mallarının değiş tokuşu sürecinden elbette ki ibaret değildir." (Alikılıç, 2016:554) Tüketici bu sırada pek çok şeyi deneyimleme firsatı bulur. "Bu bağlamda bireyler, boş zamanı da, görsel zevkleri de, tat ve kokuları, sesleri, hayalleri, arzu ve duyguları da tüketmektedirler. Keza sosyal medyayı da tüketmektedirler." (Alikılıç, 2016:554)

İçinde bulunduğumuz zaman diliminin dinamiklerine bağlı olarak, tüketim parametreleri bu bağlamda değişikliğe uğramaktadır. Tüketim bir davranış kalıbına dönüşürken, içinde bulunduğu an ve koşullar doğrultusunda şekil almaktadır. Tüketicinin seyri, içinde bulunduğumuz bilgi çağının tüketim alışkanlıkları, bireyi sosyal medya üzerinde tüketime de yönlendirmiştir. Görsel, 
duygu, fikir paylaşımı bireyde bir tatmin oluştururken, eş zamanlı olarak bireyin takip ettiği sosyal medya kanallarında neler olup bittiğini bilmek ve burada paylaşılan içerikle serbest zaman ve diğer tüketimlerine teşvik bulması, tüketim döngüsünü tamamlayan bir sürece dönüşmektedir.

Zamanın ihtiyaçları ve dinamikleri dijital iletişimi bir yaşam biçimi haline getirmiştir. Tüketilmesi gereken ürünler, teknolojideki son gelişmeler, iletişim alanındaki yenilikçi teknoloji kullanımları, bireylerin mobilize olması, daha yaygın bir biçimde tablet, cep telefonu kullanımı, bilgisayar karşısında geçirilen saatlerin artışı, bilgi toplumu olma yönündeki hızlanmaya ivme kazandırmıştır. Sosyal medya araçlarının yaygın kullanım alışkanlıkları ve uzantısı olan tüketim içiçe geçmiş durumdadır.

Günümüz koşullarında, kültür üretimi ekonominin bir parçası haline gelmiştir, bu misyonla hareket eden müze organizasyonları da temsil etmenin ve görünürlügünün sürekliliği açısından dijital mecralara yönelim bir gereklilik haline dönüşmüştür. Tüketim nesnesine dönüşme sürecinin bildik yapılardan çıkıp, internet ortamına yönlenmesi oldukça dikkat çekici bir değişimdir. "Kimin Müzesi", "şirketleşme", çok seslilik ve yorumlar için, müzeler açma baskıları olduğu kadar, bir başka baskı da "ticaretleşme"den gelmiş ve bu fikirler İnternet Müzeciliği fenomenini de etkilemiştir.” (İnel, 2000: 22)

Tüketiciye iyi zaman geçirme imkanı sağlayan çağdaş müzecilik anlayışında, standart bir gezinin haricinde, ziyaretçiye heyecan veren ve o günü yaşamasını unutulmaz kılan detaylar barındırılmaktadır. Bu tür hizmetlerin sağlanabilirliği ve bunların ziyaretçiye sunulması, müzenin koleksiyonu ve sergileme biçimleri kadar önem taşımaktadır. Bu durumu ilginç kılan unsurlar, ziyaretçiyi müzeye getirmeye yönelik hazırlanmış ve planlanmış olan dijital stratejilerden oluşan bileşenlerdir. Ziyaretçi bu durumdan bir şekilde haberdar edilmeli, buna ilgi duymalı ve bu deneyimi yaşamanın bir parçası olmalıdır.

Sayımer'e göre (2008:57) küresel çapta internet ve her türlü dijital medya kullanımının günden güne artması, iletişim sürecinin yeniden tanımlanmasını gündeme getirmektedir. Sanal ortamın yarattı̆̆ yeni iletişim uygulamaları ve sanal toplululukların giderek gelişip yaygınlık kazanması, halkla ilişkiler uygulamaları üzerinde önemli etki yaratarak, halkla ilişkiler sürecini dönüştürmektedir. Bunun sonucu olarak dijital halkla ilişkilerin temelini atan bu süreçlerle, meslek çalışanlarının, temsil ettikleri kurum ve hizmetlere yönelik erişim alanları genişlemiş, yapılan işin gerekliliklerini oluşturan, bilgi paylaşımı, hedef kitle ve paydaşları ile etkileşim içerisinde olma, sosyal sorumluluk projeleri, itibar yönetimi, kriz yönetimi, etkinlik yönetimi gibi unsurların sanal ortam üzerinden yapılabilme imkanı yaratmıştır.

Bugünün müzecilik yaklaşımında, gerek yerel gerek küresel perspektiften bakıldığında müzelerin temelinde dijital iletişimin yer aldığı görülmektedir. Tanıtımın çok yönlü yapıldığı müzelerin esas hareket noktası dijital halkla ilişkiler olmaktadır. Bilgiler saniyede değişkenlik göstermekte ve "herkes beni görsün ve bilsin" denilen gösteriş tüketiminin yaygın hale dönüştüğü gösteri toplumunda, dijital halkla ilişkiler uygulamalarını aktif ve etkin biçimde kullanabilmek, koşulan kulvarda en ön sıralarda yer almanın ön koşulu olarak görünmektedir. 
Alanyazına bakıldığında, dijital halkla ilişkiler pratikleri kapsamında en çok kullanılan araçlar; kurumsal web siteleri, elektronik postalar, çevrimiçi basın bültenleri, sosyal medya hesapları, bloglar/kurumsal bloglar, sözlük ve forumlar olarak karşımıza çıkmaktadır (Abrak, Küçüksaraç, 2017: 5045).

Günümüzde, müzelerin hedef kitlesi ile sürekli iletişimini gerçekleştirmede dijital halkla ilişkiler unsurlarını yaygın bir biçimde kullandığı görülmektedir. Çalışmanın kapsamında yer alan müzenin kullanım pratikleri dikkate alındığında, birden fazla aracın bir arada kullanımı çok yönlü iletişimi sağlamak açısından bir başlangıç noktasını oluşturmaktadır.

Önceki dönemlerde, müzeciliğin iletişim faaliyetlerine bakıldığında, hedef kitlesine bilgi aktarımı yapan, tek yönlü iletişimin daha ağırlıklı olduğu bir modelin daha yaygın olduğu, karşılıklı etkileşimin odak olmadığı görülmektedir. Sosyal medya pratiklerinin, süreçlere dahil edilmesinde daha tedbirli yol almayı prensip edinen müzelerin, oluşan temel soruları, ziyaretçilerin ne şekilde bir tutum izleyeceğine yöneliktir. Sosyal medya üzerinden paylaşımların ziyaretçileri ne yönde etkileyeceği, bu durumun müzeye olan yansımalarının ne şekilde olacağı ile ilgili sorular, uzun bir süre bu konuda ne tür tepkilerin oluşacağına dair soru işaretleri oluşturmuştur.

$\mathrm{Bu}$ gelişmelerin sonucu olarak, 21. yüzyıl medya teknolojilerinin tüketim kültürünün pazarlama - iletişim stratejilerine yansıyan etkisine paralel olarak, günümüzde kurumların hangi platformda nasıl yer almaları gerektiğini ayrıntılı şekilde düşünerek hareket ettiklerini belirten Artan, (2014:28) sosyal medyanın, sınırsız ve özgür bir iletişim alanı yaratan dijital platformlarla birlikte, pazarlama-iletişim kampanyalarının maliyetlerini de önemli ölçüde düşürmekte olduğuna işaret etmektedir. (Artan, 2014:28)

\subsection{BEŞİKTAŞ JK HAKKINDA:}

Beşiktaş JK Müzesi'ni bünyesinde barındıran, Türkiye'nin en büyük spor klüplerinden biri olan Beşiktaş JK spor klübü ile ilgili olarak genel bilgiler şu şekildedir. İlk tescil edilen ve AyYıldızlı armayı göğsünde taşıyan ilk kulüp olma özelliğini taşıyan, Beşiktaş Jimnastik Kulübü, 1903 tarihinde kurulmuştur. Siyah - Beyaz renklerle temsil edilen Kulübün kuruluş ismi, Beşiktaş Bereket Jimnastik Kulübü'dür. İlk başkan Mehmet Şamil Bey olup, ilk şampiyonluk 1911'de Jimnastik dalında alınmıştır. Futbol şubesi Ağustos 1911'de kurulmuştur. Futbol liglerine katılım tarihi 1919'dur, bu dalda ilk şampiyonluk, 1919'da Türk İdman Birliği Ligi'nde elde edilmiştir.

Tarihteki yapılanmasına biraz daha detaylı bakıldığında, kulübün başlangıcındaki ilk yapılanmanın 1902 sonbaharında Beşiktaş Serencebey Mahallesi'nde başladığı görülmektedir. O dönemde, Medine Muhafızı olan Osman Paşa'nın konağının bahçesinde, 22 kişilik genç bir grubunun belli günlerde toplanıp jimnastik hareketleri ile spor faaliyetlerine başlamışlardır. Başta Osman Paşa'nın oğulları Mehmet Şamil ve Hüseyin Bereket ile Ahmet Fetgeri, Mehmet Ali Fetgeri, Nazımnazif, Cemil Feti ve Şevket Beyler'in aralarında bulunduğu bu spor faaliyetleri tarihçenin temelini oluşturmaktadır. Özellikle odaklı olunan spor branşları, barfiks, paralel, güreş, halter, aletli ve aletsiz jimnastik şeklindedir. Bu faaliyetler Şehzade Abdülhalim tarafından desteklenmiş ve dönemin ünlü 
boksör aynı zamanda güreş sporu yapan Kenan Bey'in de antreman destekleri ile devam etmiştir.

1903 Mart'ında ise özel bir izinle Bereket Jimnastik Kulübü kuruldu. Eskrim hocası olan Fuat Balkan ile başta güreş ve halter sporlarını yapan Mazhar Kazancı, Serencebey'de jimnastik yapan gençleri bularak birlikte spor yapma fikrini kabul ettirdi. Fuat Balkan, Ihlamur'daki evinin altındaki yeri, kulüp merkezi yaptı ve Bereket Jimnastik Kulübü'nün adı Beşiktaş Osmanlı Jimnastik Kulübü olarak değiştirildi. Böylece jimnastik, güreş, boks, eskrim ve atletizmin ön planda tutulduğu güçlü bir spor kulübü meydana geldi (http://bjk.com.tr/tr/cms/tarihce/2/73/:2018).

Sonraki yıllarda da çeşitli çaba ve desteklerle Beşiktaş Osmanlı Jimnastik Kulübü, 26 Ocak 1911 tarihinde tescil edilen ilk Türk spor kulübü olmuş ve gençlerin ilgisi ve spor yapma isteği ile kulübe yönelik ilgi arttı ve üye sayısı 150'ye çıkmıştır.

“Illklerin Kulübü olarak Beşiktaş JK'nın ilk olma özelliğini taşıdığı konular şu şekildedir: Ulu Önder Atatürk'ün ilk ilgilendiği ve ziyaret ettiği Kulüp (1914), İlk kurulan Spor Kulubü (1903), ilk tescil edilen Spor Kulübü (1910), İlk spor tesisi ve lokali kuran Kulüp (Akaretler1909), İlk resmi İstanbul Ligi şampiyonu (1924), İlk eskirim şampiyonu Kulüp, İlk atletizm şampiyonu Kulüp, İlk güreş şampiyonu takım, İlk voleybol şampiyonu takım, İlk Başbakanlık Kupası, İlk Federasyon Kupası. 20 takım arasında yapılan ilk Türkiye Ligi'nde şampiyonu, Olimpiyatlara ilk defa bayan sporcu yollayan Kulüp (1936-Berlin), Ülkemizde ilk defa sahnede spor gösterisi ve jimnastik hareketi düzenleyen Kulüp (1910 / Kadiköy Apollon Sineması), İlk sualtı sporları yapan Kulüp, İlk kıtalar arası seyahat yapan Kulüp (USA), İlk boks şubesi kuran antrenörler yetiştiren Kulüp, Türkiye'de dekatlon yarışları yapan ilk Kulüp, İstanbul'da ilk defa uluslararası güreş turnuvası yöneten Kulüp (19101911), İlk maraton müsabakasını kazanan sporcu "Maratoncu İbrahim", İlk "Atış Poligonunu" kuran Kulüp, Türkiye'de Engelli Şubesi olan ilk Spor Kulübü, Dünya'da ve Türkiye' de çocuk dergisi çıartan ilk ve tek Spor Kulübü, Türkiye'de turizm şirketi kuran ilk ve tek Spor Kulübü, Türkiye'de sigorta şirketi kuran ilk ve tek Spor Kulübü, Türkiye Süper Kupası'nı (2006-2007 sezonu) kazanan ilk Spor Kulübü, UEFA Şampiyonlar Ligi'nde (2017-18), Gruplarda en fazla puan toplayan Türk takımı, Grubunu namağlup bitiren ilk Türk takımı, Grubunu lider bitiren ilk Türk takımı, Grup aşamasında en çok gol atan Türk takımı, grup aşamasında en çok galibiyet alan Türk takımı özelliğini barındırmaktadır." (http://bjk.com.tr/tr/cms/tarihce/2/83/ : 2018)

Şu anda aktif olarak, atletizm, basketbol, bedensel engelliler, boks, briç, futbol, güreş, hentbol, jimnastik, kürek, masa tenisi, satranç, voleybol konularında sportif faaliyetlerine devam eden Beşiktaş JK, önceki dönemlerde bilardo binicilik, bisiklet, eskrim, halat, çekme, halter, hokey, judo, okçuluk, su sporları konusunda da çalışmalar yapmıştır.

\subsection{BEŞİKTAŞ JK MÜZESI ÖRNEĞİ:}

Türkiye'de spor tarihi ve kültürü adına ilk spor müzesi özelliğini taşıyan Beşiktaş JK Müzesi, 11 Aralık 2001 tarihinde İnönü Stadyumu içinde Türkiye'nin ilk özel spor müzesi olarak açılmış olup Kültür ve Turizm Bakanlığı'nın 28 Haziran 2007 tarih ve 112603 sayılı onayı ile 
tescil edilmiştir. Çağdaş müzecilik perspektifiyle yenilenen müze, Şubat 2017'de ziyarete açılmıştır. Ülkemizin spor tarihine tanıklık eden Beşiktaş JK, 115 yıllık tarihini günümüz spor kültürüne kaynaklık etmek üzere hazırladığı çağdaş sergileri ile müze koleksiyonunu bilgi nesnesine dönüştürürken, ziyaretçi deneyimini esas alan uygulamaları ile konuklarını dijital dünyada keyifli bir yolculuğa çıkarmayı hedeflemiştir (http://bjk.com.tr/tr/besiktas-jkmuze : 2018).

Dolmabahçe Caddesi üzerinde yer alan ve Vodafone Park'ın tarihi 19 Mayıs kapısından girilen Beşiktaş JK Müzesi, iki kat üzerine yerleşmiş $1650 \mathrm{~m} 2$ 'lik bir alanla Türkiye'nin en kapsamlı spor müzesi olma özelliğini taşımaktadır. Müze, konumu itibarıyla kolaylıkla erişilebilir olup, Beşiktaş semt dokusuyla bir bütünlük içerisindedir.

Sergileme biçiminde bakıldığında, Kulübün kronolojisi, kuruluş tarihinden, günümüze ziyaretçilere, geçmişten günümüze yolculuk yapabilecekleri on yıllık zaman aralıkları ile ayrımlanmış alanlarda döneme ait bilgileri edinebilecekleri bilgi alanları, objeler ve dijital uygulamalar yer aldığı görülmektedir. Yalnızca futbol branşını değil, Kulüp bünyesindeki tüm spor dallarına ilişkin bilgiyi ziyaretçisiyle buluşturmak düşüncesi ile kurgulanan müze, koleksiyonu ile bağlantılı olarak sporun sanat ile iletişimini odağına alan süreli sergiler düzenlenlediği bir geçici sergi alanına da sahiptir.

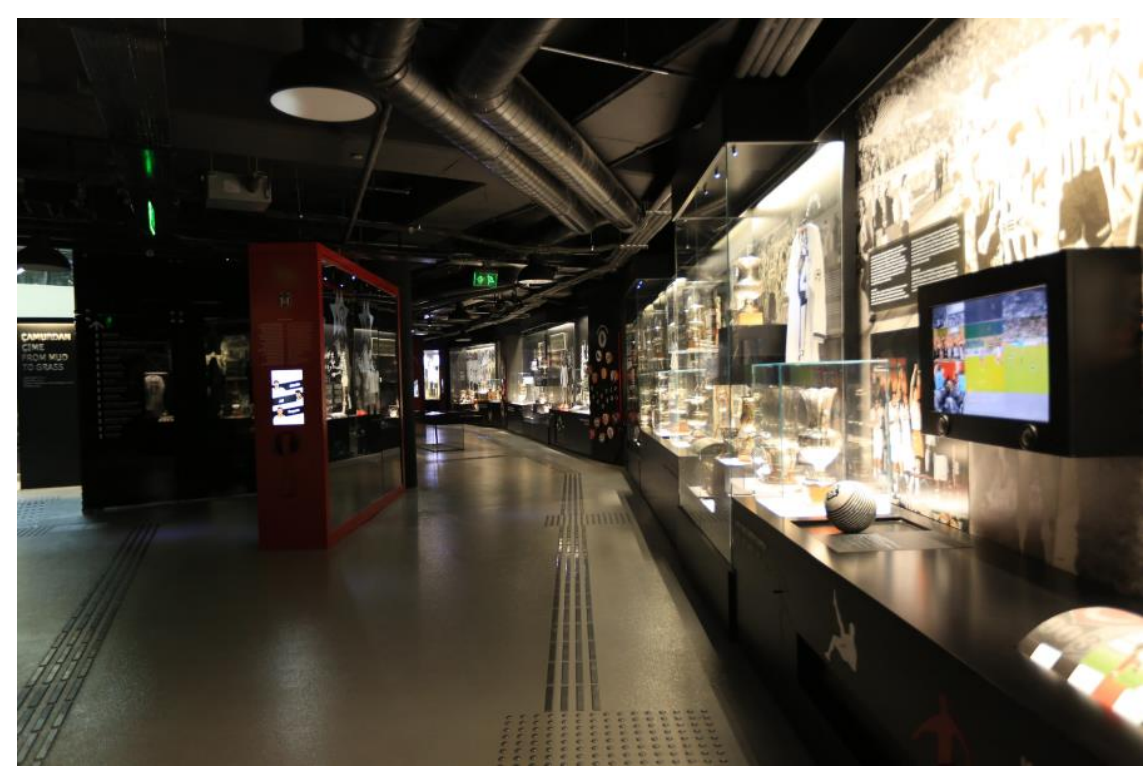

Şekil 1. Beşiktaş JK Müzesi Kesit

Ziyaretçileri ile etkileşim içerisinde olmayı esas alan, çocuklar ve gençler öncelikli olmak üzere her yaş grubu ile iletişimde olmayı amaçlayan müze, bu doğrultuda tasarlanmış uygulamaları ile ziyaretçilerine unutulmaz bir müze deneyimi yaşatmayı hedeflemektedir.

Beşiktaş JK Müzesi'nin koleksiyonu yanı sıra, müzeolojik tasarımı da ziyaretçi deneyimini odak alan uygulamaları içermektedir. Ellinin üzerinde dijital uygulama ile ziyaretçilerine eşsiz bir müze deneyimi yaşatmaktadır. Kulübün spor dalları ile ilgili bilgi sunmasının yanı sıra ziyaretçi ile etkileşimini öncelikli hedef olarak belirleyen müzedeki uygulamaların 
bazıları şunlardır: Yedek Kulübesi, kısa belgeseller alanı, dijital bilgi kioskları, sanal oyun ortamları, stat mappingleri, desibel odası, karaoke odas1, foto kabini ve roller coaster deneyimi yaşatan sanal uygulama. Ayrıca arttırılmış gerçeklik ve sanal gerçeklik kurgularının müzede çeşitli alanlarda uygulanıyor olması, müzedeki dijital anlatımların en özgün örneklerini oluşturmaktadır. Bu özellikteki kurguların yanı sıra müzenin bütününde ziyaretçinin dokunarak, izleyerek, duyarak, yaşayıp, deneyimleyebileceği ve keşfedebileceği etkileşimli pek çok alan bulunmaktadır.

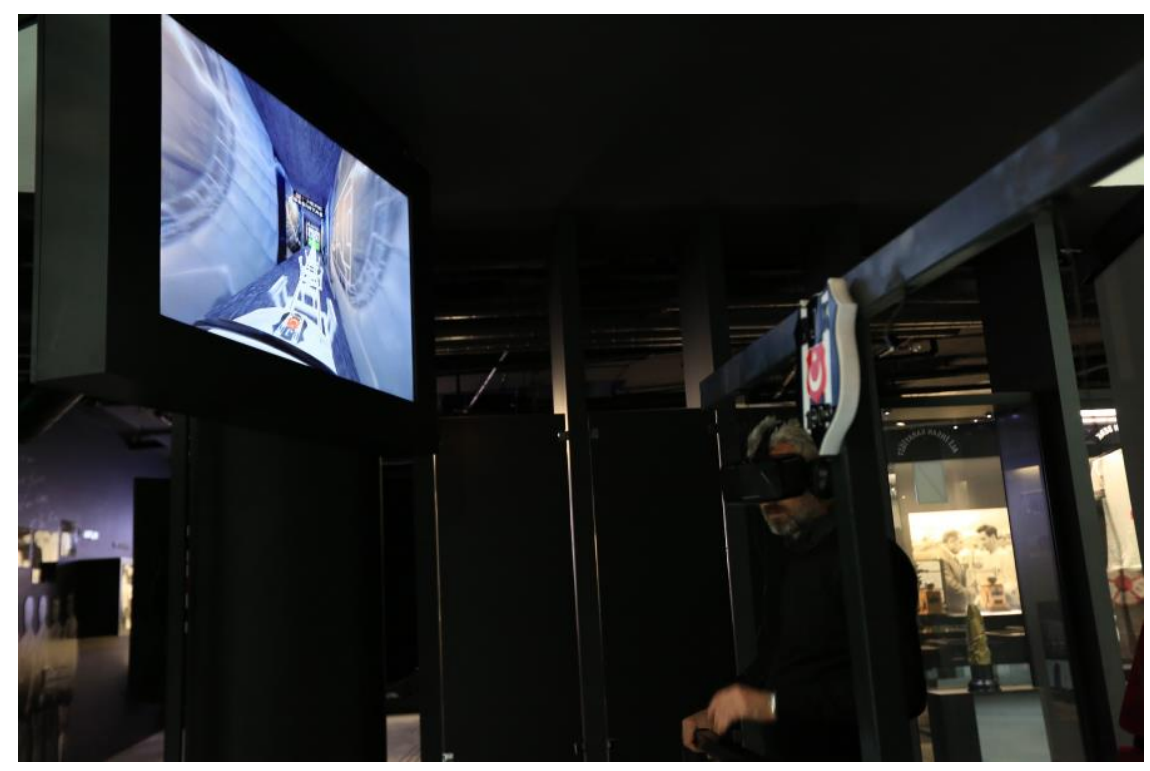

Şekil 2. Beşiktaş JK Müzesi Dijital Uygulamalar

Ziyaretçilere Yönelik Dijital Deneyim Alanı

Beşiktaş JK Müzesi, sadece bir futbol kulübü müzesi olarak değil, spor tarihine yönelik geniş bir anlatıyı toplumla paylaşmayı hedefleyen bir spor tarihi müzesi olma amacı ile yola çıkmaktadır. Sporun temsil ettiği değerleri koleksiyonu ile bir anlatıya dönüştüren müze, kronolojik anlatıları, interaktif alanları, engelli ve çocuk dostu yapısı ile tüm yaş gruplarına yönelik spor müzesi olma özelliği ile öne çıkmaktadır.

Müze, sporla sanatın buluştuğu etkinliklerle yıl boyunca tüm yaş gruplarının serbest zamanlarını verimli değerlendirdiği ve iyi vakit geçirdikleri bir öğrenme ve etkileşim ortamı sunmayı amaçlamaktadır. Tüm ziyaretçilerine spor tarihi ve kültürüne dair çok yönlü bir bakış açısı sunmaya çalışmasının yanı sıra gelecek nesillerin spor mirası ve kültürünü keşfetmeleri, bununla birlikte spora yönelik fair play, takım çalışması, centilmenlik gibi kavramların küçük yaştan itibaren kazandırılmasını hedeflemektedir.

\section{YÖNTEM:}

Türkiye'de spor müzesi olma özelliğini barındıran ve bu konuda spor tarihi ve spor kültürü açısından ilk spor müzesi özelliğini taşıyan, Beşiktaş JK Müzesi'nin dijital halkla ilişkiler pratiklerini ortaya koymayı hedefleyen bu çalışmada gözlem ve örnek olay incelemesi yöntemi araştırma tasarımı esas alınmıştır. Bu sayede, bu müzenin sanal ortamda 
gerçekleştirdiği dijital halkla ilişkiler pratikleriyle ilgili mevcut durumu ortaya koymak hedeflenmiştir.

T.C. Kültür ve Turizm Bakanlığı'nın 24.07.2018 tarihi itibari ile Bakanlık denetiminde 244 özel müze faaliyet göstermektedir. Beşiktaş JK Müzesi de bu müzelerden biridir. (http://www.kulturvarliklari.gov.tr/TR-135633/ozel-muzeler.html : 2018) Beşiktaş JK spor klübünün, spor kültürünü ve tarihini, kitlelere aktarmak amacıyla kurduğu, Beşiktaş JK Müzesi, 2007 yılında T.C. Kültür ve Turizm Bakanlığı tarafından tescil edilmiştir. Bu özelliği ile ilk tescilli spor müzesi olma özelliğini taşımaktadır. Bunun yanısıra, çağdaş müzecilik anlayışı ile tasarlanmış ilk spor müzesi olma özelliğine sahiptir. İnönü Stadı'nın Vodafone Park'a dönüşüm sürecinde, müzenin yeniden yapılandırılması ve ziyaret açılması ile birlikte, Şubat 2017 tarihinden itibaren müzenin web sitesi kullanım pratikleri ve sosyal medya hesapları aktif olarak kullanılmaya başlanmıştır. Buna ilave olarak Kulübün mobil uygulaması olan "Beşiktaş JK App" içerisinde yer alan müzeye yönelik içerikler, dijital kullanım pratikleri anlamında diğer bir örnektir. Araştırmanın nesnesi olarak web sitesi, sosyal medya araçları ve uygulama içerisinde yer alan Beşiktaş JK Müzesi'ne yönelik içerikler belirlenmiştir.

\section{ARAŞTIRMA BULGULARI:}

Dijital halkla ilişkiler pratikleri açısından bakıldığında, Beşiktaş JK Müzesi'nin en odaklı kullandığı araçlar kurumsal web sitesi, sosyal medya hesapları ve Beşiktaş JK resmi mobil uygulaması içerisinde (Beşiktaş JK App) yer alan Beşiktaş JK Müzesi'ne yönelik bilgi bölümüdür. Kulübün resmi mobil uygulamasında Beşiktaş JK ile ilgili bilgilerin yanı sıra, müze ile ilgili özgün içeriklerin yer aldığ görülmektedir.

Müzenin web sitesine erişimi, Beşiktaş JK resmi sitesi www.bjk.com.tr üzerinden yapılmaktadır. Müzenin web alan bilgisi www.bjk.com.tr sitesi yatay düzlemde yer alan kategori başlıklarından biri olarak yer almaktadır. Müzenin adresi http://bjk.com.tr/tr/besiktas-jk-muze şeklindedir. Web sitesi kurumsal kimlik bilgileri dikkate alınarak hazırlanmıştır. Beşiktaş JK Müzesi konu başlığına tıklandığında erişilebilen sitede, konu başlıkları müzeye ilişkin bilgileri ve işbirliği oluşturduğu konularla ilgili içerikleri kapsamaktadır. İlk sekmede müzenin genel tanıtımına ilişkin bilgiler yer verilmiştir. Bu alanda müzenin tanıtımına yönelik bir video ve "hakkımızda" başlığı altında müze hakkında açıklayıcı bilgiler bulunmaktadır. Ziyaret günleri ve ücretler sekmesinde; müzenin ziyaretler günleri ve saatleri, kapalı olduğu günler ve tarihler gibi ziyarete yönelik bilgi yer almaktadır. Giriş ücretlerinin yer aldığı bu bölümde, müze ziyareti esnasında alınabilecek bilgiler yer verilmektedir. Müzede Öğrenme sekmesinde okul gruplarına yönelik turlar ve yetişkinler için rehberli turlara ilişkin bilgi ve bu turlara katılmak için gerekli olan rezervasyon bilgileri yer almaktadır.

Genel anlamda biçimsel unsurlar açısından değerlendirildiğinde, müzenin web sitesinin genel görünüşü iyi olduğu, sade, anlaşılır, yazı fontları rahatlıkla okunabilir ve erişiminin kolay olduğu görülmektedir. 
Beşiktaş JK Müzesi, müzede öğrenme programları kapsamında çeşitli dönemlerde atölyeler düzenlemektedir. Bu atölyelere yönelik içeriklerin anlatıldığı Yaz Atölyeleri sekmesinde, müzede düzenlenmiş olan çocuklara atölyelere yer verilmektedir. Yaz döneminde düzenlenen Spor ve Çağdaş Sanat Atölyeleri, Müzede Ses, Sporla Dans, Müzede Ritmini Keşfet, Spor Yazarlığı ve Muhabirlik Atölyesi düzenlenmiştir. Bu atölyelere yönelik kısa açılamalar ve bu atölyelere yönelik kısa tanıtım videoları bu bölümde yer almaktadır.

Haberler sekmesinde, müzeye yönelik haberler yer almaktadır. Haberlere yönelik fotograf ve kısa açılamaların yer aldı ̆̆ı bu bölmede, haber detayları www.bjk.com.tr haberler sekmesi içerisinde yer almaktadır. Haber içeriklerine genel olarak bakıldığında, müze işbirliği ile oluşturulan Semt Turu, çocuk atölyeleri, müzenin tanıtımına yönelik farklı mecralarda yayınlanan haberlerden seçkiler, kutlamalar, sergiler ve ziyaret konulu haberlere yer verilmiştir.

Basında biz sekmesinde ise, dergi, gazete ve haber portallerinde Beşiktaş JK Müzesi'ne yönelik haberlerden seçkiler yer almaktadır. Haber içeriklerde müzenin, en kapsamlı spor tarihi müzesi olması, çocuk odaklı yaklaşımı, engelli dostu bir müze olduğu vurgulanırken, spor alanında kültürel birikimin, günümüzün uygulamaları ile başarılı bir biçimde harmanlanmasına değinilmektedir. Dijital uygulamaları olan ve ziyaretçi etkileşimini esas alan uygulamalara yönelik bir müze olduğundan bahsedilmektedir.

Galeri sekmesinde, müze koleksiyonu ve sergilenme alanı içerisinde yer alan, dijital alanlar ve ziyaretçi deneyimini esas alan örneklere yer verilmiştir. Bu bağlamda Desibel Odası, Kartal Uçuşu ve Belgesel alanına yönelik tanıtım videoları bu bölümde yer almaktadır. Bu alanda aynı zamanda çeşitli konularda fotograf albümlerine yer verilmiştir. Bu konular genel olarak sporcuların ziyaretleri, genel ziyaretler, etkinlikler, düzenlenen atölyeler, kutlamalar, sergiler, açlışlar, lansmanlar ve müzeden kesitler olarak kategorize edilebilir. Bu konu başlıkları sayfa üzerinde ikonlar olarak yer almaktadır. İkonlara tıklanarak fotograf albümüne ulaşılabilmektedir.

Bağışlarla ilgili sekmede ise, müzenin arşiv, koleksiyon ve kütüphane birimlerinin koordinasyonunda oluşturulmuş olan, dökümanlara yer verilmiştir. Müzenin bu konuda oluşturmuş olduğu standartlar ve politikalar çerçevesinde hazırlanmış olan Dijital ve Fiziksel Arşiv Yönetmeliği ve Dijital ve Fiziksel Arşiv Bağış formu yer almaktadır.

Bize Ulaşın kısmında ise, irtibat telefonu, genel sorulara yönelik bir e-mail irtibat adresi, eğitim ve atölyelere yönelik olarak, müzede öğrenme bölümü e-mail adresi, sosyal medya hesap bilgisine yer verilmiştir. Bunun haricinde müzeye erişim ve ulaşım bilgileri paylaşılmış olup, otopark kullanım koşulları bilgisi, posta adresi ve google haritası yer almaktadir.

Şeref Turu sekmesinde ise, Beşiktaş JK bünyesinde yer alan, ziyaretçilerine bir stadyum deneyimi yaşatan "Şeref Turu" uygulamasına yer verilmiştir. Birkaç cümle ile Şeref Turu ürününe dair genel bilgiye yer verilmiş olup, ne tür bir kapsamı olduğuna değinilmiş, web sitesine yönlendiren bir link eklenmiştir. Buna ilave olarak Şeref Turu'nun kullanmakta olduğu Facebook, Twitter ve Instagram hesaplarına yönelik hesap bilgileri paylaşılmıştır. 
Sayfanın en son sekmesi ise Semt Turu'dur. Müzenin yakın dönemde duyurulan Kara Kartal'ın İzinde Beşiktaş Semt Turunu anlatan bu bölümde, tura ilişkin genel bilgiler, tur tarihleri ve katılım koşulları gibi bilgilerin yanı sıra; turdan bahseden A5 föy, tur rotası ve geçmişten günümüze Beşiktaş'1 anlatan bir fotograf galerisi dosyaları indirilebilir formatta ziyaretçilerin ve geziye katılanlara bilgi sağlaması açısından bu alana yüklenmiştir. Tur rotası ve tur rehberinin mesleki bilgileri çalışmanın son kısmını oluşturmaktadır.

Web sitesinde dikey bir banner uygulaması dikkat çekmektedir. Dikey uygulama ile müze sayfasının sol kısmında konumlandırılan bu banner, Beşiktaş JK Müzesi ve Deniz Müzesi arasında imza edilen karşılıklı işbirliği protokülüne yönelik bir bilgidir. Ziyaretlerde karşılıklı indirim uygulamasını içeren bir bilgiye yer vermektedir.

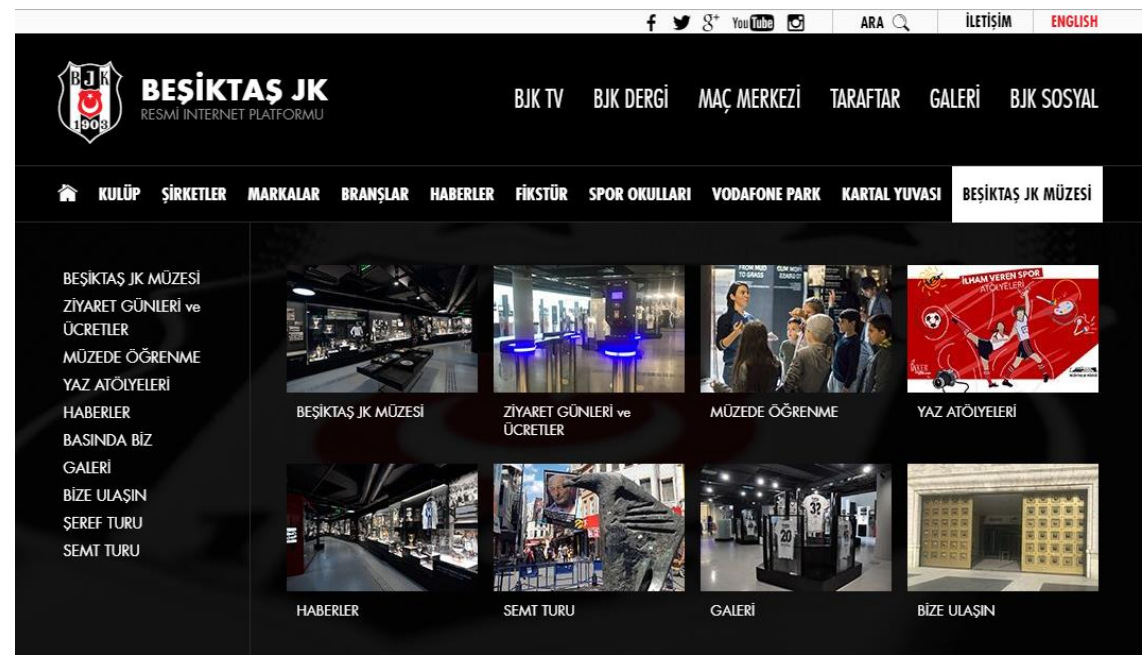

Şekil 3. Beşiktaş JK Müzesi Web Sitesi

Web sitesinin içeriksel unsurları açısından bakıldığında, hedef kitlesine yönelik olarak, müzeye yönelik genel bilgiler, sunulan hizmetler genel fikir veren ve açıklayıcı bir anlatım dili ile oluşturulmuş olduğu görülmektedir.

Web sitesinde daha çok bilgilendirmeyi ve ziyaretçinin ilk aşamada sormak istediği konu ve konu grupları göz önünde bulundurularak, temel anlatıları içeren bir dil kullanıldığ gözlemlenmektedir. Ziyaretçi müzenin sağladığı hizmetlere yönelik fikir edinebilmekte ve bu seçeneklerden faydalanmak için web üzerinden ne şekilde iletişime geçebileceğine dair fikir sahibi olabilmektedir.

Sosyal medya hesaplarına bakıldığında, Instagram, Twitter ve Facebook hesaplarının aktif olarak kullanıldığı görülmektedir. Bahsi geçen hesapların hepsi mavi tik almıştır. 21 Ekim 2018 tarihi itibarıla, Instagram hesabında, 46.7B takipçisi bulunmakta olup toplamda 572 paylaşım yapılmıştır. Twitter'da ise 22.663bin takipçisi bulunmaktadır ve 678 paylaşımı sözkonusudur. Facebook hesabında 582 paylaşım yapılmış olup, 6023 beğeni ve 6132 takipçisi bulunmaktadır. 
Sosyal medya hesaplarındaki konu başlıklarına bakıldığında, şu şekilde bir akış gözlemlenmektedir: Müzenin açıldığı döneme ilişkin ağırlıklı olarak müzenin ziyaret bilgileri ve ziyaretçi profile ve yapılan ziyaretlerle ilgilidir. Özel günler ve kutlamalara yönelik içeriklerin yer aldığı paylaşımlarda, müzenin genel tanıtımı, Uzun Salı uygulaması ve kampanyalar, iş birliktelikleri, anma ve kutlama mesajları, televizyon çekimleri hakkında bilgilendirme, maç günlerine yönelik uygulamalar ve Kulübün spor tarihinden müze ile ilişkilendirilmiş seçkilere yer verilmiştir. Çocuk dostu bir müze olması nedeniyle içeriklerde çocuklara yönelik düzenlenen atölyeler ve okul gezileri paylaşım konularından bir diğeridir. Sergiler, geziler ve aktivitelere yönelik olarak iletilerin de yer aldığı paylaşımlarda, müzenin koleksiyonu kadar, güncel yaşamda yer alan uygulamaları ve Vodafone Park içerisinde yer alan alanlarla olan etkileşimi de bu paylaşımlarda dikkati çekmektedir.

Beşiktaş JK mobil uygulması olan Android ve IOS platformlarında sunulan ve cep telefonlarına indirilen bu uygulamada Beşiktaş JK Müzesi de yer almaktadır. Uygulamanın ana sayfasında alt kısmında yer alan Beşiktaş JK Müzesi ikonundan ulaşılan alanda, müzeye dair genel bir bilgi metnine yer verilmiştir. Müzeye yönelik bilgilerin yer aldığı bu alanda, Türkiye'nin en kapsamlı spor müzesi olması, koleksiyon nesneleri, kütüphane alanı, tasarımının deneyim ve etkileşim odaklı müzecilik anlayışı ile yapıldığı ve içerisinde yer alan dijital uygulamalara yer veren bir anlatı bulunmaktadır. Eş zamanlı olarak müzenin engelli dostu tasarımına yönelik bilgiler ve çocuklara yönelik alanlarla ilgili anlatılara yer verilmiştir.

Bu çalışmalara, dijital halkla ilişkiler perspektifinden bakıldığında ise, ilk hareket noktasının hedef kitleye yönelik bir bilgilendirme amacı içerdiği görülmektedir. Çocuk, genç ve yetişkin olmak üzere, farklı hedef kitlelere seslenmeyi amaçlayan müze dijital halkla ilişkiler araçlarında, farklı yaş gruplarına yönelik ileti ve bilgilendirmelerin olduğu, bu bilgilendirmelerin açık ve net bir anlatımla ziyaretçisine ulaşmayı benimsediği gözlemlenmektedir. Buna ilave olarak, basın, çeşitli kuruluşlar ve pek çok paydaş ile irtibatta olan müzenin bu mecralara yönelik genel bir içerik yapısı olduğu görülmüştür. Eş zamanlı olarak bu mecraların kullanım pratiklerine bakıldığında, aidiyet, deneyim yaşama gibi unsurları teşvik eden bir uslüp benimsediği dikkati çekmektedir.

İçeriğin son kısmında ise, ziyaretçilere genel bilgi vermesi açısından ziyaret günleri ve ücretler hakkında bilgi verilmektedir. Sayfanın son kısmında ise Müze Galerisine Git şeklinde bir yönlendirme ikonu bulunmaktadır. Bu ikon ile mobil uygulamanın galeriler kısmına erişilmektedir. Bu kısımda genel galeri bölümünde Beşiktaş JK Müzesi'ne yönelik bir galeri yer almaktadır. Ekranın üst kısmında semte ve Beşiktaş JK tarihi ile ilişkili fotograflara yer verilmiştir. Görsellerin alt kısmında sergi, müze tanıtımı, müzedeki sergi ve etkileşimli alanlarına ait videolar bulunmaktadır. Bu videolar, Mayıs 2018 döneminde açılan Formalar Sergisi tanıtım videosu, bir simülasyon alanı olan Desibel Odası videosu, Belgesel Alanı videosu, 1.Yıl Kutlaması ve Star Wars Helmet Sergisi videoları şeklindedir. Bu alanın alt kısmında ise İlk branşlar, Beşiktaş JK Müzesi logolar, 1920 - 1940’lar, 1950 - 1980'ler, 1990-2000'ler, 100.Y1l, Kişiler, Avrupa Bölümü'nde bu konulara yönelik görsel arşivlerden kesitler bulunmaktadir. 
Bu bölümün alt kısmında ise, Vodafone Park'ta ziyaretçilerine stadyum deneyimi yaşatan Şeref Turu'na dair bir tanıtım video mesajı bulunmaktadır. Beşiktaş JK Müzesi tanıtım videosunun yer aldığı bölümün takibinde, müze içerisinde yer alan galerilerden örnek verilerek, arşivde yer alan fotograflardan bir seçkiye yer verilmektedir. Müze tanıtımının yer verildiği diğer bir videoda ziyaretçi deneyimini vurgulayan içeriklerle hazırlanmış bir bilgilendirme videosu olarak yer almaktadır. Sonraki video içeriğinde ise dijital deneyim alanı olan Kartal Uçuşu videosuna yer verilmiştir. Bu bölümde yer alan en son video çalışması müzenin tarihi, genel koleksiyonu ve dijital uygulamalara dair kesitleri içeren bir tanitım videosudur.

\section{SONUÇ VE DEĞERLENDİRME}

Spor müzelerinin dijital halkla ilişkiler pratiklerini İstanbul'daki bir spor müzesi üzerinden betimlemeyi amaçlayan çalışmada, araştırmanın örneklemi Türkiye'de spor tarihi ve spor kültürü açısından ilk spor müzesi özelliğini taşıyan, Beşiktaş JK Müzesi ile sınırlandırılmıştır. Müzenin dijital halkla ilişkiler uygulamaları açısından; tanıtım ve iletişim faaliyetlerinin sürekliliği anlamında, güncellenen bir web sitesine sahip olması, sosyal medya hesaplarını aktif şekilde kullanan bir müze olması araştırma gerekçesini oluşturmaktadır.

Gözlem ve örnek olay analizi yönteminin kullanıldığı çalışmada elde edilen veriler neticesinde, analiz kapsamında bulunan spor müzesinin dijital halkla ilişkiler pratiklerinin hedef kitlesi ile iletişimin devamlılığı ve kullanılan dilin müze hakkında genel bilgiler aktarmayı hedeflemesinin yanı sıra, ziyareti ve deneyimini destekleyici bir işlev oluşturduğu görülmüştür.

Spor müzeleri, genel anlamıyla, spor tarihine yönelik kültürel belleği gelecek nesillere aktarma misyonunu üstlenmiştir. Koleksiyonu çerçevesinde, bir anlatım dili benimseyen müzelerin, ziyaretçisi ve hedef kitlesi anlamında benimsediği genel misyonu yanı sıra görünmeyen pek çok rolü de üstlendiği görülmektedir. Dijital halkla ilişkiler kapsaminda oluşturulan anlatım dilinde, müzenin sporu seven herkesin ziyaret edebileceğini ifade eden bir söylem kullandığı görülmektedir. Bunun yanı sıra Beşiktaş JK Müzesi, bulunduğu semtin tarihinden ve kimliğiyle bütünleşmiş bir müze olup, müze içerisinde bu kurguyu özenli bir şekilde sunmaktadır. Bu bağlamda içerisinde bulunduğu il ve semtin kültür ve tarih ekosistemine katkıda bulunmaktadır.

Vodafone Park, spor faaliyetlerine ev sahipliği yapmasının yanı sıra serbest zaman faaliyeti alternatifi olması açısından da kayda değer örneklerden birini temsil etmektedir. Beşiktaş JK Müzesi'nin ziyaretçi deneyimini esas alan, spor tarihi konusunda özgün bir müze olmasının yanında Vodafone Park'ta keyifli vakit geçirebilecek birçok alternatif alan yer almaktadır. Kahve deneyimi adına Blackcup Coffee, dijital oyun oynamak için Lenovo Game On oyun alanı, Beşiktaş JK markalı ürünlerin ve müze hatıralık eşya alternatiflerinin yer aldığı Kartal Yuvası ve etkinlik organizasyonlarının yapıldığı mecralar bu yapılanmanın parçalarını oluşturmaktadır. Bunun yanı sıra şehir içi tur tanıtım ve müze iş ortaklıkları, Beşiktaş JK bünyesinde yer alan, bir stadyum deneyimi yaşatan Şeref Turu ve son dönemde müze 
bünyesinde geliştirilen; semtin hafıza mekanlarıyla Beşiktaş JK değerlerini harmanlayan bir tur çalışması olan Semt Turu müzenin diğer işbirliklerini oluşturmaktadır.

$\mathrm{Bu}$ şekildeki bir yapılanma müzenin ziyaretçi kitlesine sunduğu hizmet çeşitliliğini artırırken, ziyaretçisine yönelik içerik oluşturmasındaki kaynaklardan biri olarak yer almaktadır. Müzenin koleksiyonu, etkinlikleri (atölyeler, sergiler vb.), özel günler, kutlamalar, klüp mesajlarının retweet ve repost edilmesi, ziyaretler, bilgilendirmeler, yaş gruplarına yönelik oluşturulan iletilerin yanısıra bu tür iş birliklerinin de sosyal medyada içerik olarak kullanıldığı görülmektedir.

Müzenin yeniden yapılanması ve açılması oldukça yeni olup, yaklaşık 18 aylık bir süreci kapsamaktadır. Bu anlamda en temel sosyal medya araçları ile müzenin yapılanmasına ve topluma iletmek istediği mesaja yönelik olarak ileti paylaşımında bulunmaktadır. Burada spor tarihini temsil eden bir misyon edinmesi ve bu anlamda sosyal medya ile bağ kuran ilk müze olması nedeniyle ayırd edici bir rol üstlenen Beşiktaş JK Müzesi aynı zamanda hazırladığı içeriğin niteliği kısmında da farklılık oluşturmaya özen göstermektedir.

Beşiktaş JK Müzesi, iletişim çalışmaları kapsamında pek çok farklı mecra ile irtibatta bulunmaktadır. Farklı mecralarla olan çalışmalarının yanı sıra Beşiktaş JK sosyal medya ekibi, BJK TV ve Beşiktaş Dergisi ile çalışmalar üretmekte, bu konuda iletişim alanını genişlettiği görülmektedir.

Beşiktaş JK Müzesi, yeni bir müze olmasına karşın, uygulamakta olduğu dijital iletişim faaliyetleri ile Türkiye'deki spor müzeleri açısından özgün bir örnek oluşturmaktadır. Bu alanda ilk olması, bu tür çalışmalar yapmayı planlayan spor müzelerine yönelik bilgi sağlayıcı ve ilham veren bir başlangıç noktası olabilir.

Dijital halkla ilişkiler konusunda var olan çalışmaların farklı sosyal medya pratikleri ile örtüştürülmesi müzenin tanıtım ve etkileşimi için bu alanda bir ilk olma özelliğini gelecek dönemlerde daha ileriye taşıması açısından fayda yaratabilir. Dijital iletişim politikaları çerçevesinde ve hedef kitlesine daha etkin ulaşmak adına farklı coğrafyalarda yer alan ziyaretçi kitlelerine yönelik olarak, Google Art uygulaması etkin hale getirilebilir. Yine müze içerisinde yer alan artırılmış gerçeklik uygulaması ve simülasyon özelliği benzeri uygulamaları dijital mecralara da taşıması, ziyaretçiye fikir vermesi ve ziyaretçi deneyimini teşvik etmesi açısından etki yaratabilir.

Sporun insanları birleştirici gücü ve eğlendirici yanları esas alınarak, sosyal medya üzerinden yarışmalar, web üzerinden oyunlaştırma faaliyetleri gibi uygulamaların yanı sıra app üzerinden tarihçe ile ilgili hazırlanmış içerikler ve spor tarihinde iz bırakan kişilere ve olaylara yönelik anlatılar ziyaretçinin dijital halkla ilişkiler sürecine dahil olması için sonraki dönem iletişim planlarında yer verilebilir. Etkinliklere yönelik web üzerinde daha detaylı bilgi yer alması, belli bir konuda sporun destekleyici rolü adına blog alanı açılması da ziyaretçi etkileşimini artıracak önemli unsurlar olarak dikkate alınabilir.

Spor müzelerine yönelik yapılacak araştırmalar açısından bakıldığında ise, ülkemizde yeni bir alan olması bağlamında, pek çok araştırma konusuna olanak yaratacak bir çalışma alanı 
ortaya çıkmaktadır. Öncelikle bir deneyim alanı olma yönünde ilerleyen müzeler, deneyim pazarlaması ve ziyaretçi deneyimi açısından ele alınabilir, bunun yanı sıra hedef kitlelere yönelik oluşturulan pazarlama iletişimi unsurları, müze içi sergileme ve uygulama unsurlarının incelenmesi de sahaya katma değer sağlayacak çalışmalar olarak ön görülmektedir.

\section{KAYNAKÇA}

Abrak, E. Küçüksaraç, B. (2017) Postmodern Müzelerde Dijital Halkla İlişkiler ve Deneyimsel Pazarlama Pratikleri: İstanbul'daki Postmodern Müzelere Yönelik Nitel Bir Araştırma. Journal of Human Sciences 14 (4) 5040-5054.

Alikılıç Aşman, Ö. (2011). Halkla İlişkiler 2.0 Sosyal Medyada Yeni Paydaşlar, Yeni Teknikler Ankara: Efil Yayınevi

Altunbaş, H. (2007). Sporun Pazarlanması ve Pazarlama İletişiminde Spor, Selçuk İletişim, Journal of Selçuk Communication 5 (1) 93 - 101.

Artan, E.Ç. (2014) Peki Ya Ziyaretçi Gelmezse? Müzeler ve Medya, Genç Sanat Aylık Güzel Sanatlar Dergisi No:232 25-29.

Bridgewater, S. (2012). Futbol Markaları. Brandage Yayınları.The Brandage, Marka Fabrikası İletişim ve Reklam Ltd.Şti. No:10 İstanbul

Erkal, M. E. (1986). Sosyolojik Açıdan Spor. T.C.Milli Eğitim ve Spor Bakanlığı Beden Terbiyesi ve Spor Genel Müdürlügü. Yayın No: 30 Ankara: Milli Eğitim Basımevi

İnel, B. (2000) "Çağdaş Müzeciliğin Temel Yapısı" 5. Müzecilik Semineri Bildiriler 20 - 22 Eylül 2000, Askeri Müze ve Kültür Sitesi Komutanlığı, Harbiye İstanbul, 20 - 29.

Katırcı, H. (2009). Türk Futbolunda Kurumsal İletişim Yönetimi, Gazi Beden Eğitimi ve Spor Bilimleri Dergisi Ekim 2009, XIV(4), 65-75.

Katırcı, H. Uztuğ, F. (2009). Spor Kulüplerinde İletişim Yönetimi: Türkiye Profesyonel Futbol Liglerinde Yer Alan Spor Kulüplerinin İletişim Uygulamalarına İlişkin Bir Araştırma. Anadolu Üniversitesi Sosyal Bilimler Dergisi Cilt:9 Sayı/No: 1149 - 168.

Korkmaz, S. (2013). Spor Müzelerinin İşlevleri ve Bir Spor Müzesi Taslağının Yönetsel Açıdan Oluşturulması. İstanbul (T.C. İstanbul Üniversitesi, Sosyal Bilimler Enstitüsü, Müze Yönetimi Programı, Yüksek Lisans Tezi)

Sayımer, İ.(2008). Sanal Ortam Halkla İlişkiler, İstanbul, Beta Yayınları

Yıldız, D. (1979). Türk Spor Tarihi. Eko Matbaası, İstanbul

www.bjk.com.tr E. T. : 20.10.2018

http://bjk.com.tr/tr/cms/tarihce/2/73/ E. T. : 20.10.2018

http://bjk.com.tr/tr/cms/tarihce/2/83/ E. T. : 20.10.2018

www.bjk.com.tr/tr/besiktas-jk-muze E. T.: 06.10.2018

www.kulturvarliklari.gov.tr/TR-135633/ozel-muzeler.html E. T.: 06.10.2018 